\title{
Dynamics in mangroves assessed by high-resolution and multi-temporal satellite data: a case study in Zhanjiang Mangrove National Nature Reserve (ZMNNR), P. R. China
}

\author{
K. Leempoel ${ }^{1, *}$, B. Satyaranayana ${ }^{1,2,3}$, C. Bourgeois ${ }^{1}$, J. Zhang ${ }^{4}$, M. Chen ${ }^{4}$, J. Wang ${ }^{5}$, J. Bogaert ${ }^{6}$, and \\ F. Dahdouh-Guebas ${ }^{1,2}$ \\ ${ }^{1}$ Laboratory of Systems Ecology and Resource Management, Département de Biologie des Organismes, Faculté des Sciences, \\ Université Libre de Bruxelles-ULB, Avenue Franklin D. Roosevelt 50, CPI 264/1, 1050 Brussels, Belgium \\ ${ }^{2}$ Laboratory of Plant Biology and Nature Management, Mangrove Management Group, Vrije Universiteit Brussel-VUB, \\ Pleinlaan 2, 1050 Brussels, Belgium \\ ${ }^{3}$ Institute of Oceanography and Environment (INOS), Universiti Malaysia Terengganu (UMT), 21030 Kuala Terengganu, \\ Malaysia \\ ${ }^{4}$ Administration Bureau of Zhanjiang Mangrove National Nature Reserve (ZMNNR), Huguang township, Mazhang District, \\ Zhanjiang City, 524088 Guangdong Province, China \\ ${ }^{5}$ Guangdong Ocean University (GDOU), Xiashan District, Zhanjiang City, 524025 Guangdong Province, China \\ ${ }^{6}$ Biodiversity and Landscape Unit, Université de Liège, Gembloux Agro Bio Tech, Passage des Déportés 2, 5030 Gembloux, \\ Belgium \\ * now at: Laboratory of Systems Ecology and Resource Management, Département de Biologie des Organismes, Faculté des \\ Sciences, Université Libre de Bruxelles-ULB, Avenue Franklin D. Roosevelt 50, CPI 264/1, 1050 Brussels, Belgium
}

Correspondence to: K. Leempoel (kleempoe@ulb.ac.be)

Received: 20 December 2012 - Published in Biogeosciences Discuss.: 13 February 2013

Revised: 3 July 2013 - Accepted: 14 July 2013 - Published: 27 August 2013

\begin{abstract}
Mangrove forests are declining across the globe, mainly because of human intervention, and therefore require an evaluation of their past and present status (e.g. areal extent, species-level distribution, etc.) to implement better conservation and management strategies. In this paper, mangrove cover dynamics at Gaoqiao (P. R. China) were assessed through time using 1967, 2000 and 2009 satellite imagery (sensors Corona KH-4B, Landsat ETM+, GeoEye-1 respectively). Firstly, multi-temporal analysis of satellite data was undertaken, and secondly biotic and abiotic differences were analysed between the different mangrove stands, assessed through a supervised classification of a high-resolution satellite image. A major decline in mangrove cover $(-36 \%)$ was observed between 1967 and 2009 due to rice cultivation and aquaculture practices. Moreover, dike construction has prevented mangroves from expanding landward. Although a small increase of mangrove area was observed between 2000 and $2009(+24 \%)$, the ratio mangrove/aquaculture
\end{abstract}

kept decreasing due to increased aquaculture at the expense of rice cultivation in the vicinity. From the land-use/cover map based on ground-truth data $(5 \times 5 \mathrm{~m}$ plot-based tree measurements) (August-September, 2009) as well as spectral reflectance values (obtained from pansharpened GeoEye1), both Bruguiera gymnorrhiza and small Aegiceras corniculatum are distinguishable at 73-100\% accuracy, whereas tall $A$. corniculatum was correctly classified at only $53 \%$ due to its mixed vegetation stands with $B$. gymnorrhiza (overall classification accuracy: $85 \%$ ). In the case of sediments, sand proportion was significantly different between the three mangrove classes. Overall, the advantage of very high resolution satellite images like GeoEye-1 $(0.5 \mathrm{~m})$ for mangrove spatial heterogeneity assessment and/or species-level discrimination was well demonstrated, along with the complexity to provide a precise classification for non-dominant species (e.g. Kandelia obovata) at Gaoqiao. Despite limitations such as geometric distortion and single panchromatic band, the $42 \mathrm{yr}$ old 
Corona declassified images are invaluable for land-use/cover change detections when compared to recent satellite data sets.

\section{Introduction}

Mangroves provide a wide array of ecological and economic benefits (Dahdouh-Guebas and Koedam, 2006a; DahdouhGuebas et al., 2006a; Nagelkerken et al., 2008; Walters et al., 2008). However, they are presently considered as one of the most threatened ecosystems in the world (Duke et al., 2007). In fact, mangroves once fringing $\sim 75 \%$ of tropical coasts (Chapman, 1976) are reduced to about $25 \%$ mainly due to human intervention (Rönnbäck, 1999); recent estimates on global mangrove cover indicate between 137760 and $152000 \mathrm{~km}^{2}$ of mangrove forest remaining in 123 countries and territories (Giri et al., 2011; Spalding et al., 2010). In general, mangrove denudation at the rate of $2.1 \%$ annually is much higher than the loss of tropical forests and coral reefs (Valiela et al., 2001).

This constant pressure on mangrove ecosystems underlines the demand for mangrove biogeographical data and vegetation maps (produced at species level and areal extent) that can ultimately be used by local authorities for better conservation and management practices (Masso i Aleman et al., 2010). With the difficulty of conventional monitoring techniques in mangrove environments, the data obtained from aerial and/or satellite remote sensing sensors became essential, particularly when analysing vegetation history and dynamics (Dahdouh-Guebas and Koedam, 2008). The coarse resolution of most remote sensors (e.g. Landsat, SPOT, etc.) provides enough information to discriminate mangroves at the species level but only for large and homogeneous stands. In mangrove research, both spatial and spectral resolution need to be high to enable delineation of small patch size of certain species. In this context, modern sensors like IKONOS $(1 \mathrm{~m})$, QuickBird $(2.4 \mathrm{~m})$ and GeoEye-1 $(0.5 \mathrm{~m})$ provide very high resolution (VHR) images that enable spotting voluminous single trees on the ground (Dahdouh-Guebas et al., 2004). Overall, remote sensing, combined with ground-truth observations in a GIS environment, remains time-saving as well as cost-effective for qualitative and quantitative assessment of the mangrove vegetation (Dahdouh-Guebas, 2002; Dahdouh-Guebas et al., 2006b; Satyanarayana et al., 2011; Green et al., 2000).

The main objective of the present study was to analyse the spatial heterogeneity of different mangrove species at Gaoqiao (Leizhou Peninsula, China) using ground-truth and high-resolution satellite imagery (GeoEye-1 data). Firstly, a diachronic observation of three satellite images (obtained from Corona KH-4B, Landsat ETM+ and GeoEye-1) enabled the assessment of land cover change and mangrove extent over a $42 \mathrm{yr}$ period (1967-2000-2009). Secondly, abi- otic and biotic factors influencing local mangrove distribution were compared between the different mangrove stands, assessed through a supervised classification of the very high resolution GeoEye-1 satellite image.

\section{Materials and methods}

\subsection{Study area}

The study was conducted near Gaoqiao (facing the Gulf of Tonkin on Leizhou Peninsula) in southern China (Fig. 1), where the mangroves are managed by the Zhanjiang Mangrove National Nature Reserve (ZMNNR). The conservation area in Leizhou Peninsula has been estimated to be 20000 ha of which 12375 ha consist of the actual mangrove vegetation that occurs in discontinuous patches and fringes along the coast, mostly because of aquaculture activities. The remaining area (7625 ha) consists of mudflats potentially suitable for mangrove propagation (Chen et al., 2009; ZMNNR, 2010). The historic extent of mangroves on Leizhou Peninsula was estimated at 14027 ha in 1957 (Gao et al., 2009). Being the largest mangrove wetland in China ( $\mathrm{Li}$ and Lee, 1997; Chen et al., 2009), its rich biodiversity was represented by 22 mangrove species (Gao et al., 2009), 82 bird species, 48 gastropods and shellfish species, and 11 finfish species (Ramsar, 2009). The study zone of Gaoqiao considered for the present investigation comprises 2000 ha of mangrove $\left(21^{\circ} 33^{\prime} 55^{\prime \prime} \mathrm{N}\right.$ and $\left.109^{\circ} 45^{\prime} 17^{\prime \prime} \mathrm{E}\right)$, represented by seven mangrove species including Aegiceras corniculatum (L.) Blanco, Avicennia marina (Forssk.) Vierh., Bruguiera gymnorrhiza (L.) Lamk., Excoecaria agallocha L., Kandelia obovata (Sheue), Rhizophora stylosa Griff., and Sonneratia apetala (Buch.-Ham). A Ramsar status (no. 1157) was conferred to the whole ZMNNR in January 2002. Plantations in open areas are mostly constituted of $B$. gymnorrhiza.

The study area is influenced by a northern tropical climate with the mean annual temperature of $23^{\circ} \mathrm{C}$ and precipitation of $1500 \mathrm{~mm}$ (Gao et al., 2009). The coldest and hottest days are during January and July, respectively. The rainfall, with uneven rates of precipitation, lasts from May to September. The tides are diurnal with a salinity between 20 and $23 \%$, and $\mathrm{pH}$ from 7.6 to 7.8 (Liang and Dong, 2004).

\subsection{Fieldwork}

Data on mangrove vegetation, pore-water salinity and sediment characteristics were collected along nine transects (running perpendicular to the coast/creek line) in $5 \mathrm{~m} \times 5 \mathrm{~m}$ area plots at $50 \mathrm{~m}$ intervals (Fig. 1). A total number of 70 plots, located in the main stands of the high tide area, were studied between 6 August and 8 September, 2009. The geographical coordinates of all plots were obtained using a handheld global positioning system (Garmin, GPS $60^{\mathrm{TM}}$, USA) (accuracy $<6 \mathrm{~m}$ ). In each plot, the vegetation data consisted of tree identification, height (m) and girth $G_{130}$ measurements (the 


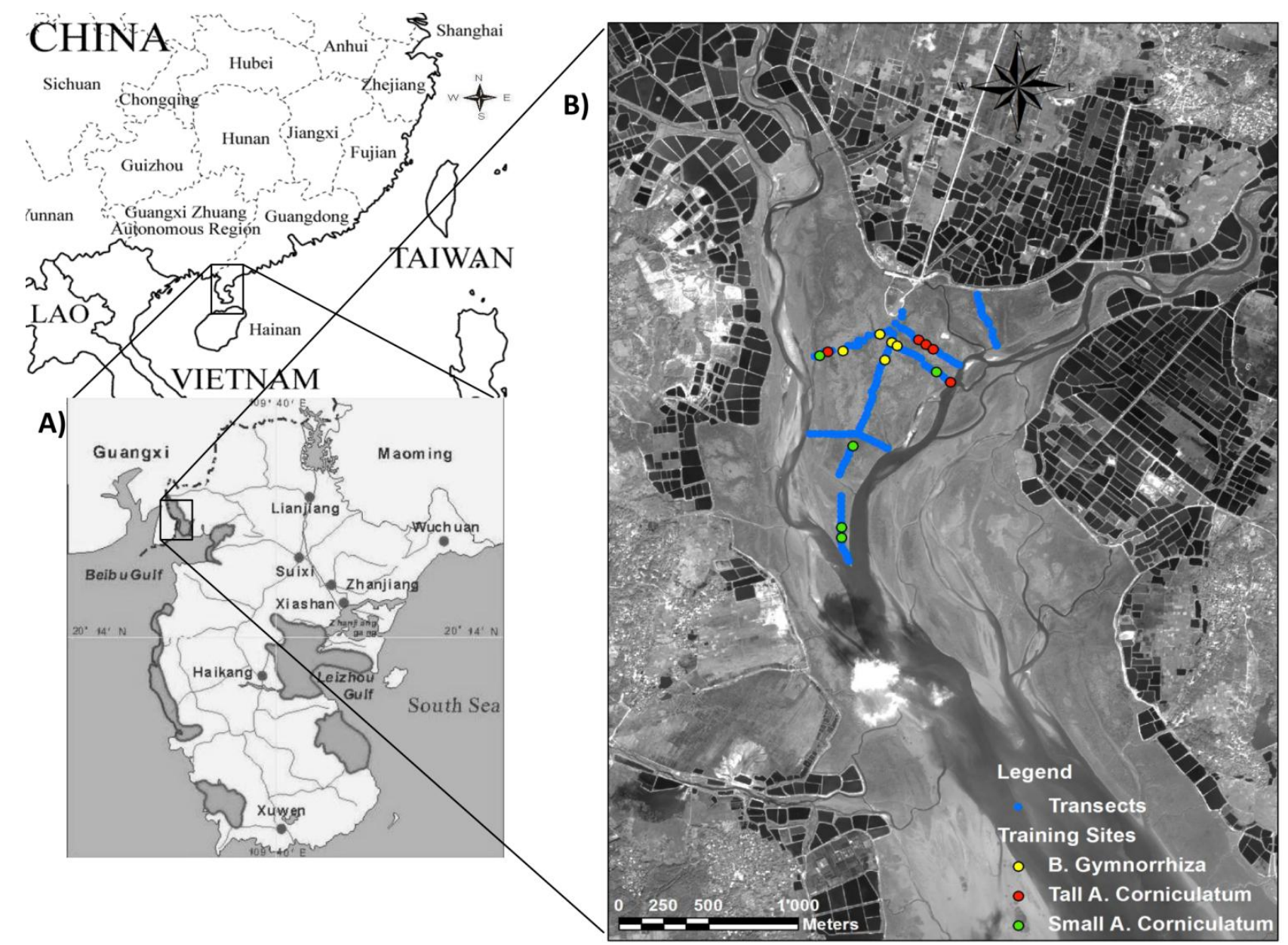

Fig. 1. (A) Mangrove areas found in Leizhou Peninsula of southern China, and (B) pansharpened multispectral GeoEye-1 satellite (2009) imagery showing Gaoqiao mangrove cover facing the Gulf of Tonkin. The ground inventory has been carried out in transects (blue points) running perpendicular to the coast/creek line. Training sites used for the supervised classification of the three mangroves classes are indicated in yellow, red and green points.

girth at $130 \mathrm{~cm}$ height along the tree, which was subsequently converted into the diameter $-D_{130}$ ). In the case of trees smaller than $130 \mathrm{~cm}$, girth was measured at $10 \mathrm{~cm}$ height $\left(G_{010}\right)$. This kind of situation was encountered mostly for small A. corniculatum, which formed pure stands and thus is not problematic for the class assignment method used. In addition, most $A$. corniculatum individuals were constituted of several stems deeply anchored in the mud, making the distinction between individual trees and stems almost impossible. It was therefore decided to measure all stems instead in each plot. Based on these measurements, different tree

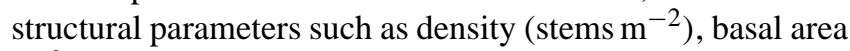
$\left(\mathrm{m}^{2}\right)$, relative density $(\%)$, dominance $(\%)$ (i.e. relative basal area), and relative frequency (\%) were estimated using standard formulae (Cottam and Curtis, 1956; Cintron and Schaeffer Novelli, 1984; Dahdouh-Guebas and Koedam, 2006b).

The pore-water salinity (from a $20 \mathrm{~cm}$ deep hole dug into the ground) was measured at three different areas (randomly chosen) within each plot using a hand refractometer (Atago ${ }^{\circledR}$, MASTER-S/Mill $\alpha$, Japan). A soil sample $(\sim 250 \mathrm{~g})$ was collected from each plot and analysed for its textural content through hydrometer method (Bouyoucos 1962). Soils samples were analysed at the Soil Laboratory of the Agriculture College in Guangdong Ocean University.

\subsection{Remote sensing}

Three satellite images (namely from panchromatic Corona KH-4B, a recently declassified US military programme (dated 17 December 1967), spatial resolution: $1.8 \mathrm{~m}$; the pansharpened Landsat ETM+ (30 October 2000), spatial resolution: $15 \mathrm{~m}$; and the pansharpened GeoEye-1 (16 October 2009), spatial resolution: $0.5 \mathrm{~m}$ ) were used to identify changes in mangrove and adjacent land-use/cover (e.g. aquaculture) patterns. All images were projected under the same projection system (WGS_1984_UTM_Zone_49N). 
The panchromatic Corona image was obtained from the United States Geological Survey (USGS), and georeferenced using ground control points (GCPs) against the GeoEye-1 (ArcMap v. 9.3.1). Since it contains only single-band information, the supervised and/or un-supervised classification techniques were not supported. Instead, the mangrove area in 1967 was extracted by on-screen digitization. As the aquaculture ponds were not easily recognizable in 1967, the mangrove / aquaculture ratio was calculated only for 2000 and 2009.

Both GeoEye-1 (satellite image produced by GeoEye) and Landsat ETM+ (courtesy of the U.S. Geological Survey) images were subjected to pansharpening (applying Brovey transformation and nearest-neighbour resampling technique in ERDAS IMAGINE ${ }^{\circledR}$ v. 8.5) for clear identification of the features. In the case of recent (2009) data, the pansharpened NDVI (normalized difference vegetation index) layer of GeoEye-1 was added to the pansharpened multispectral image of GeoEye-1 as a band. Supervised classifications of mangrove and aquaculture cover were carried out on both images using maximum likelihood classification to achieve better accuracy (Green et al., 2000).

Discrimination of current mangrove stands was only performed on GeoEye-1 image. All aforementioned species were sampled during fieldwork; however, only B. gymnorrhiza and A. corniculatum formed large pure stands. Within mangroves, three different classes were defined by five mangrove plots each through the training sets of the signature editor (Fig. 1) (Neukermans et al., 2008; Satyanarayana et al., 2011). Bruguiera gymnorrhiza training sites were defined by the five highest values of dominance while the two classes of A. corniculatum (i.e. tall A. corniculatum and small A. corniculatum) were defined by high dominance as well as average tree height (five highest and five smallest respectively) (Table 1). Other classes in the supervised classification included water, sand, open area (i.e. grassland), and aquaculture ponds (in total seven classes including mangroves). Finally, the accuracy assessment of the land-use/cover map was carried out using confusion matrix with 113 GCPs scattered across mangrove and non-mangrove areas.

\subsection{Correlation between dominant vegetation and abiotic factors}

Information on soil texture and pore-water salinity for each plot was regrouped according to the mangrove class of the plot. One-way analysis of variance (ANOVA) was applied to test whether the means of the groups were equal, while Student's $t$ tests (with Bonferroni correction) were used to compare two groups. For some data sets, however, conditions of application for using ANOVA were not observed. In such cases, the Kruskal-Wallis test substituted the ANOVA, and the Wilcoxon rank sum test replaced the Student's $t$ test. All statistical tests were computed using R (R Development Core Team, 2010).
Table 1. Relative dominance and average height of A. corniculatum and $B$. gymnorrhiza in sample plots used to define mangrove classes for supervised classification (maximum likelihood classification) in ZMNNR, Gaoqiao, China.

\begin{tabular}{lllcr}
\hline & & \multicolumn{2}{c}{ Relative dominance (\%) } & \\
\cline { 3 - 4 } & Plot & $\begin{array}{c}\text { Aegiceras } \\
\text { corniculatum }\end{array}$ & $\begin{array}{c}\text { Bruguiera } \\
\text { gymnorrhiza }\end{array}$ & $\begin{array}{r}\text { Tree } \\
\text { height } \\
(\mathrm{cm})\end{array}$ \\
\hline ID & & & & 304 \\
Bruguiera & A07 & 0.00 & 0.96 & 244 \\
& B02 & 0.04 & 0.96 & 234 \\
& B06 & 0.01 & 0.95 & 332 \\
& D01 & 0.04 & 0.92 & 302 \\
\hline Aegiceras & A05 & 0.06 & 0.89 & 313 \\
corniculatum & C05 & 0.80 & 0.20 & 311 \\
(tall) & D03 & 0.62 & 0.38 & 308 \\
& C04 & 1.00 & 0.00 & 292 \\
& B07 & 0.68 & 0.29 & 265 \\
\hline Aegiceras & F04 & 0.68 & 0.32 & 89 \\
corniculatum & B08 & 1.00 & 0.06 & 83 \\
(small) & D06 & 1.00 & 0.00 & 74 \\
& AE04 & 1.00 & 0.00 & 66 \\
& F05 & 1.00 & 0.00 & 61 \\
\hline
\end{tabular}

\section{Results}

\subsection{Mangrove cover dynamics}

Between 1967 and 2009, mangrove degradation occurred along the landward sides of Gaoqiao (Fig. 2). The most perceptible change was mainly observed on its southeast corner where a large mangrove stand has been converted into rice culture and aquaculture ponds, delimited by a new dike. Similarly, mangroves in the north, adjacent to main water channels, were cleared for the same reason. Changes in the river course pattern were also evident at some places in the north (Fig. 2). Time-series data revealed that certain rice fields were replaced by aquaculture ponds between 2000 and 2009 . In this context, the dike limits remained the same with only those aquaculture developments on its landward side (Fig. 2). At the same time (i.e. between 2000 and 2009), the mangrove / aquaculture ratio at Gaoqiao decreased despite a small increase (192 ha) of mangrove cover (Table 2).

\subsection{In situ observations on plant and animal diversity}

Along transects, A. corniculatum was the most predominant species (63/66 plots) followed by B. gymnorrhiza (44/66) and $K$. obovata (29/66). The relative density of $A$. corniculatum was also high in most plots ( $90 \%$ on average) when compared to B. gymnorrhiza (7\%) and K. obovata (2\%). However, canopy cover is better estimated using dominance $(69 \%$ on average for A. corniculatum, $22 \%$ for B. gymnorrhiza, 


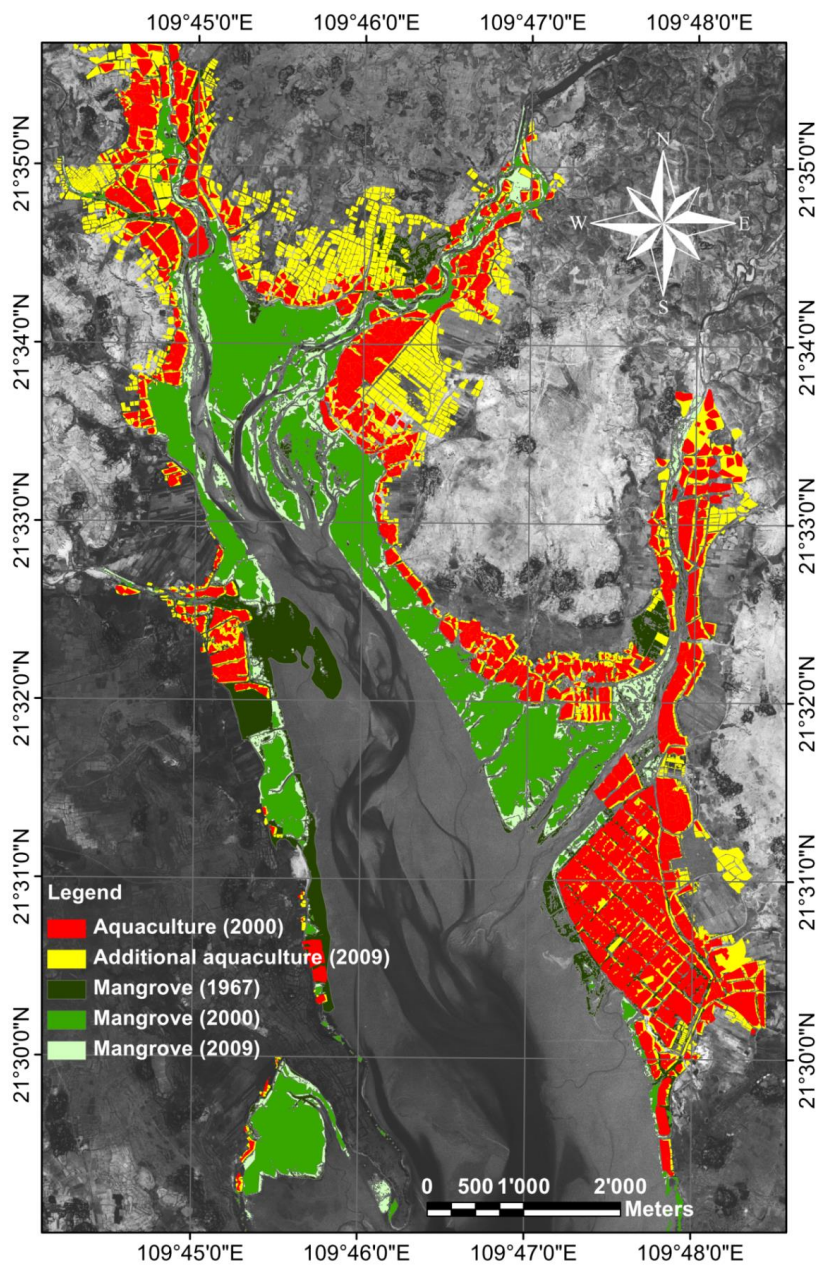

Fig. 2. Changes in Gaoqiao mangrove cover observed from 1967 (Corona), 2000 (Landsat) and 2009 (GeoEye-1) satellite data and expansion of aquaculture ponds observed from 2000 (Landsat) and 2009 (GeoEye-1) satellite data (background: 1967 Corona imagery).

and $6 \%$ for $K$. obovata) than with relative density, making dominance, in this case, more appropriate for a supervised classification of remote sensing imagery. No understory was observed, except for seedlings. E. agallocha was seen rarely but always surrounded by a circle of $2-3 \mathrm{~m}$, clear of vegetation. Three crab species (Sesarma bidens (De Haan, 1835), Parasesarma affinis (De Man, 1895) and Uca arcuata (De Haan, 1833)) which may have a role in nutrient dynamics in soil were identified. The overload of barnacles on the leaf and stems of A. corniculatum and Avicennia marina (trees present along the major water channels) might be also an important growth-affecting factor at Gaoqiao.

\subsection{Land-use/cover classification}

Spectral reflectance values of the seven land-use/cover classes were separable (Fig. 3). Aquaculture and water

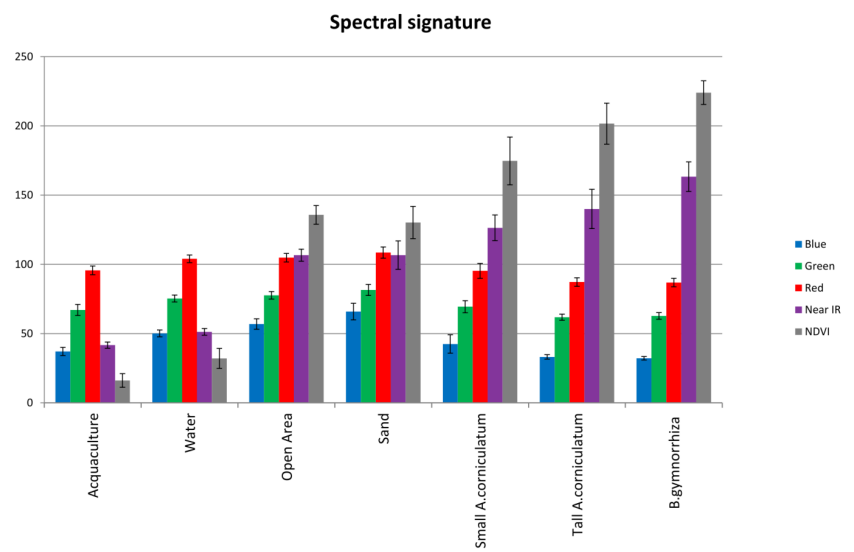

Fig. 3. Spectral reflectance (intensity of each band) of the landuse/cover classes used for supervised classification of Gaoqiao mangrove and adjacent areas.

classes were distinguished primarily by the blue and NDVI bands. In contrast, differences between open areas and sand classes were found to be small. For the mangrove classes, although values were similar for the blue and green bands, their differentiation in the red, near infrared (NIR), and NDVI bands was considerably high. The highest value for NDVI was found for B. gymnorrhiza, followed by tall A. corniculatum and small A. corniculatum (Fig. 3).

\subsection{Mangrove distribution}

In agreement with the aforementioned spectral characteristics, the supervised classification (Fig. 4) provided satisfactory results. The interior position of B. gymnorrhiza could be noticed as a single patch with a few smaller ones nearby. Tall A. corniculatum was present in the northern part of the study zone and along the major water channels, whereas small A. corniculatum was mostly distributed in the peripheral margins and close to open areas. While aquaculture, open area and small $A$. corniculatum classes were represented by higher accuracy, others such as water and dike/sand, including two mangrove classes (i.e. tall A.corniculatum and B. gymnorrhiza), were less well delineated. Tall A. corniculatum had a low accuracy (53\%) owing to the fact that nearly seven plots were misclassified from B. gymnorrhiza to tall A. corniculatum (Table 3).

The sediments at Gaoqiao were predominantly of a clayeysilt nature (Table 4). Sand content was high at small A. corniculatum sites, and it also revealed significant differences between the mangrove classes. In contrast, clay and silt content as well as salinity varied less and remained insignificant among classes. 
Table 2. Extent, difference and mangrove/ aquaculture ratio of mangrove and aquaculture areas (1967-2000-2009) in ZMNNR, Gaoqiao, China.

\begin{tabular}{cccccc}
\hline Year & $\begin{array}{c}\text { Aquaculture } \\
\text { area } \\
\text { (ha) }\end{array}$ & $\begin{array}{c}\text { Difference } \\
\text { with }\end{array}$ & $\begin{array}{c}\text { Mangrove } \\
\text { area } \\
\text { (ha) }\end{array}$ & $\begin{array}{c}\text { Difference } \\
\text { with }\end{array}$ & $\begin{array}{c}\text { Mangrove/ } \\
\text { aquaculture } \\
\text { ratio }\end{array}$ \\
\hline 1967 & - & - & 1967 & - & - \\
2000 & 707.2 & - & 583 & $-51.8 \%$ & 0.82 \\
2009 & 994.1 & $28.9 \%$ & 775 & $-35.9 \%$ & 0.78 \\
\hline
\end{tabular}

Table 3. Confusion matrix showing accuracy assessment of the supervised land-use/cover classification for Gaoqiao, China.

\begin{tabular}{|c|c|c|c|c|c|c|c|c|c|}
\hline Class & $\begin{array}{l}\text { Aqua- } \\
\text { culture }\end{array}$ & Water & Sand & $\begin{array}{r}\text { Open } \\
\text { area }\end{array}$ & $\begin{array}{l}\text { Small } \\
\text { A. cor. }\end{array}$ & $\begin{array}{l}\text { Tall } \\
\text { A. cor. }\end{array}$ & $\begin{array}{l}\text { B. gymn- } \\
\text { orrhiza }\end{array}$ & $\begin{array}{l}\text { Row } \\
\text { total }\end{array}$ & $\begin{array}{r}\text { Producer's } \\
\text { accuracy }(\%)\end{array}$ \\
\hline Aquaculture & 24 & 0 & 0 & 0 & 0 & 0 & 0 & 24 & 100 \\
\hline Water & 1 & 20 & 0 & 0 & 0 & 0 & 0 & 21 & 95 \\
\hline Sand & 0 & 0 & 33 & 2 & 0 & 0 & 0 & 23 & 91 \\
\hline Open area & 0 & 0 & 0 & 8 & 0 & 0 & 0 & 8 & 100 \\
\hline Small A. corniculatum & 0 & 0 & 0 & 0 & 11 & 0 & 0 & 11 & 100 \\
\hline Tall A. corniculatum & 0 & 0 & 0 & 0 & 2 & 10 & 7 & 19 & 53 \\
\hline B. gymnorrhiza & 0 & 0 & 0 & 0 & 0 & 4 & 11 & 15 & 73 \\
\hline Column total & 25 & 20 & 33 & 10 & 13 & 14 & 18 & 133 & \\
\hline User's accuracy (\%) & 96 & 100 & 100 & 80 & 85 & 71 & 61 & & 85 \\
\hline
\end{tabular}

\section{Discussion}

\subsection{Mangrove cover changes}

Mangrove degradation has been reported substantially since increasing pressure of rice cultivation is exercised. Twothirds of the original mangrove coverage disappeared in the last $50 \mathrm{yr}$, especially between 1960 and 1970s, due to deforestation, land reclamation for aquaculture or tourist resorts and urbanization activities (Li and Lee, 1997; Chen et al., 2009; Chen and Ye, 2011; Spalding et al., 2010; Ren et al., 2008). At Gaoqiao, $39.5 \%$ of mangrove cover was lost in the past four decades (1967-2009) for rice cultivation and aquaculture practices for shrimps and crabs (Fig. 2). After acquiring the Ramsar site of international importance, the dike which was constructed previously did not change, but the type of land use inside the dike area was shifted from rice cultivation to aquaculture ponds. Nevertheless, the negative impacts of aquaculture on mangrove vegetation and the booming of this industry during the 1980-1990s for economic reasons are well known (Rönnbäck, 1999; DahdouhGuebas et al., 2002; Primavera, 1998; Hamilton et al., 1989). In fact, in order to filter nitrogen and phosphorus loads within a mangrove ecosystem, several authors suggest a minimum sustainable ratio for mangrove and aquaculture areas proposed at 2-22 ha of forest per 1 ha of aquaculture, depending on the study (Robertson and Phillips, 1995; Costa-Pierce, 2002; Primavera et al., 2007). In the case of Gaoqiao, the mangrove / aquaculture ratio is $<1$ and continued to decrease in 2009 (Table 2) due to aquaculture expansion. In addition, the actual mangrove cover (i.e. 775 ha) estimated using 2009 GeoEye-1 satellite imagery was found to be much lower than the area (i.e. 2000 ha) projected by Ramsar (2009). Therefore a revision of the area statistics should be considered.

\subsection{Land-use/cover classification}

In addition to B. gymnorrhiza and both tall and small A. corniculatum, we also tried to provide supervised classes for $S$. apetala, $K$. obovata and the mixed mangrove stands of A. corniculatum-A. marina sampled on the southern transect, in addition to B. gymnorrhiza and both tall and small A. corniculatum stands. However, due to its lower dominance and limited coverage, the accuracy of the classified map was poor with unrealistic species' distribution and therefore ignored. Overall, the importance of NIR and NDVI bands for (dominant) mangrove species discrimination at Gaoqiao was evident (Fig. 3). Despite of the same species, a clear-cut difference in the spectral reflectance of tall and small A. corniculatum sites was remarkable. This could be due to both variation in their greenness/biomass and the dominance of B. gymnorrhiza in tall A. corniculatum class (18\%) compared to small A. corniculatum class $(3 \%)$. This latter hypothesis may also explain the misclassified plots of tall A. corniculatum in the B. gymnorrhiza class (Table 3). 
Table 4. Sediment and salinity characteristics at three mangrove classes in ZMNNR, Gaoqiao, China. The average and standard deviation values as well as their significance level are indicated $(\alpha=0.05$ with Bonferroni correction for multiple test $=0.017)$. Significant results are bold.

\begin{tabular}{|c|c|c|c|c|c|c|c|c|}
\hline & $\begin{array}{l}\text { Sand } \\
(\%)\end{array}$ & & $\begin{array}{l}\text { Silt } \\
(\%)\end{array}$ & & $\begin{array}{l}\text { Clay } \\
(\%)\end{array}$ & & $\begin{array}{l}\text { Average } \\
\text { salinity }(\%)\end{array}$ & \\
\hline B.gymnorrhiza & $0.22 \pm 0.15$ & & $0.31 \pm 0.13$ & & $0.47 \pm 0.18$ & & $6.2 \pm 4.5$ & \\
\hline Tall A.corniculatum & $0.23 \pm 0.15$ & & $0.35 \pm 0.13$ & & $0.42 \pm 0.14$ & & $8.3 \pm 5.1$ & \\
\hline Small A.corniculatum & $0.38 \pm 0.16$ & & $0.31 \pm 0.15$ & & $0.32 \pm 0.14$ & & $9.4 \pm 5.7$ & \\
\hline Analysis of variance & Kruskal-Wallis & $\mathrm{df}$ & Kruskal-Wallis & $\mathrm{df}$ & Kruskal-Wallis & $\mathrm{df}$ & Kruskal-Wallis & $\mathrm{df}$ \\
\hline & 0.009 & 55 & 0.2791 & 55 & 0.0405 & 55 & 0.1861 & 53 \\
\hline $\begin{array}{l}\text { Average of the } \\
\text { difference }\end{array}$ & Wilcoxon & & Wilcoxon & & Wilcoxon & & Wilcoxon & \\
\hline $\begin{array}{l}\text { B.gymnorrhiza }= \\
\text { Tall A.corniculatum }\end{array}$ & 0.5823 & & - & & 0.3025 & & - & \\
\hline $\begin{array}{l}\text { B.gymnorrhiza }= \\
\text { Small A.corniculatum }\end{array}$ & 0.0184 & & - & & 0.0343 & & - & \\
\hline $\begin{array}{l}\text { Tall A.corniculatum = } \\
\text { Small A.corniculatum }\end{array}$ & 0.0046 & & - & & 0.0381 & & - & \\
\hline
\end{tabular}

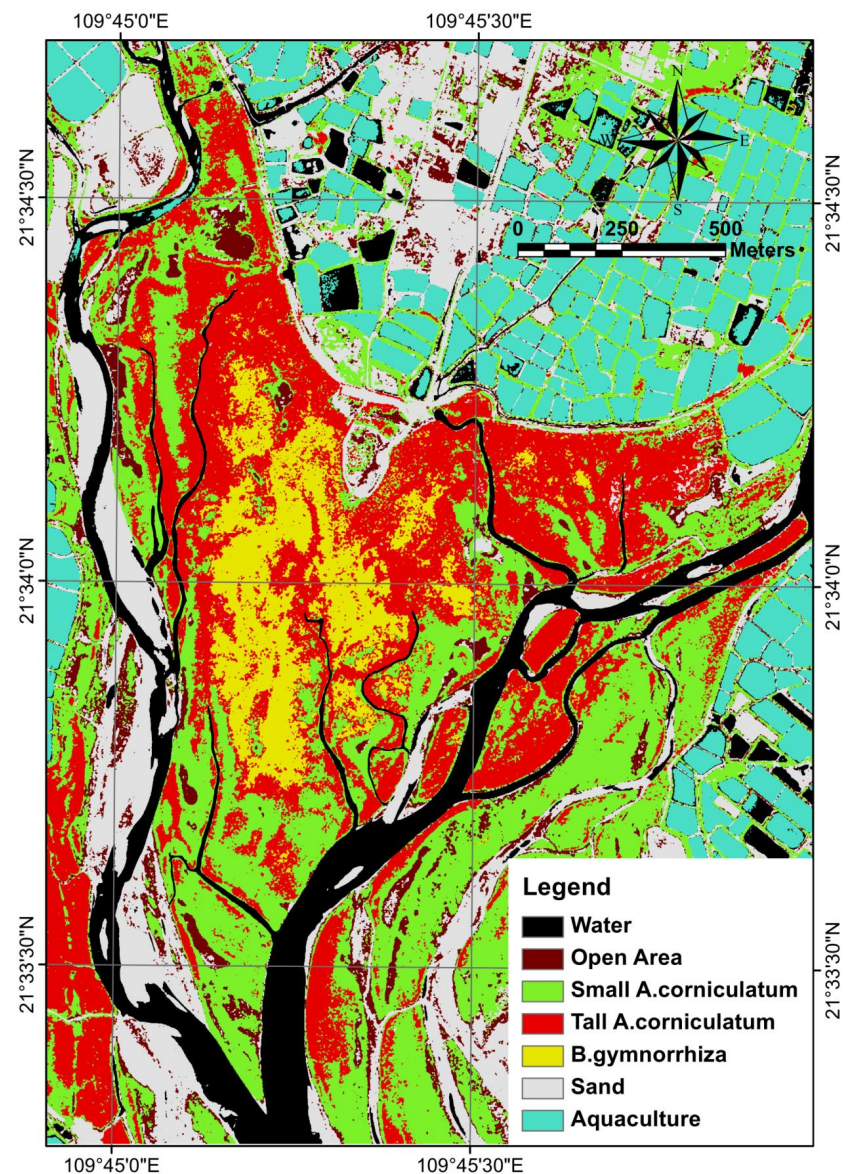

Fig. 4. Land-use/cover supervised classification of Gaoqiao based on the pansharpened multispectral GeoEye-1 (2009) image, and the fieldwork transects shown in Fig. 1.

\subsection{Current mangrove distribution}

In addition to earlier records from mangrove regions close to Hong Kong, Yingluo Bay and Leizhou Bay (Tam et al., 1997; Ye et al., 2005; He et al., 2007; Ren et al., 2008; Gao et al., 2009; Ramsar, 2009), the present study highlights the dominance of A. corniculatum. However, previous studies do not report dominance of $B$. gymnorrhiza, which could be explained by different areas (even in the same region) supporting different species in relation to their size and geographic location (sea or landward), freshwater runoff and the extent of inundation in Gaoqiao.

For example, species like B. gymnorrhiza are usually characteristic of interior sites away from main flooding channels (Ye et al., 2003; Satyanarayana et al., 2010), and this might be the reason for its abundance inside the forest (Fig. 4). Kandelia obovata being more tolerant to water logging than B. gymnorrhiza (Ye et al., 2003) was found along small permanent watercourses and waterlogged areas. In fact, water channels in the study zone are often boarded by the tall A. corniculatum class, and it is in these areas that most $K$. obovata individuals exist. Open areas in the upper intertidal and supralittoral zones were the last to be inundated, as was observed in situ, and this may explain the very low density of propagules and the absence of mangroves observed in these areas, indicating their limited transport by water.

The intriguing pattern of tall $A$. corniculatum and small A. corniculatum distribution observed along the convex and concave creek sides, respectively (Fig. 4), is likely to correspond to accretion and erosion zones (Fig. 2), suggesting an important role of currents on the dynamics of habitats and vegetation regeneration. The low average salinity $(8.5 \%$ ) in the high tide area of Gaoqiao could be due to the present 
sampling in the rainy season and also to constant freshwater input from Ximi and Qaoqiao rivers flowing into Yingluo Bay. Therefore, a pioneer mangrove species like A. marina, which occupies the frontier edge of the tidal flat (i.e. low tidal flats) in China (Ye et al., 2005; Ren et al., 2011), was found essentially in the southernmost transect. However, the salinity in mangroves close to Gaoqiao was reported to be $23 \%$ o (Liang and Dong, 2004). This important difference of measurement could explain why no significant correlation was found with salinity. An important point is the observation of old A. marina sites in the northern part of the study area, which may reflect an ancient disjunct zonation of this species restrained by parasitism or by man.

Mangrove-associated species such as Cerbera manghas L. and Ipomoea pes-caprae L. have mostly occupied the elevated grounds where tidal inundation is less frequent. They also colonize, mixed with some mangrove species (A. Corniculatum, E. Agallocha), along the banks of rivers and small streams inland that supply the rice fields. This abrupt transition in zonation along the land-sea gradient inside the mangroves and the presence of landward mangrove species both testify a restricted zonation in light of the artificial barrier (i.e. dike construction) at Gaoqiao.

\section{Conclusions}

The applicability of very high resolution imagery such as GeoEye-1 for mangrove spatial heterogeneity assessment and species-level discrimination, along with its difficulty to provide a precise classification for non-dominant species, has been demonstrated in the present study. If the mangrove stand size is considerable, it is possible to identify the same species (e.g. A. corniculatum) with different heights using GeoEye-1 NIR imagery even when present with different tree heights. In addition, the use of $42 \mathrm{yr}$ old Corona satellite imagery, compared to newly derived satellite data (e.g. GeoEye1), allowed studying mangrove and other land-use/cover dynamics. While mangrove destruction between 1967 and 2000 was associated with the land reclamation for agriculture and aquaculture practices, conversion of agricultural fields into aquaculture ponds, between 2000 and 2009, was also responsible for the decrease of mangrove/aquaculture ratio. The mangrove extent over 775 ha at Gaoqiao appeared to be determined largely by its geographic (sea or landward) location. The overwhelming dominance of A. corniculatum (which is known as "river mangrove") coincides with strong freshwater input in the vicinity. However, no environmental factors measured were able to discriminate $B$. gymnorrhiza and tall A. corniculatum stands.

Knowing the current status of mangrove distribution at Gaoqiao, we suggest that further studies (involving both remote sensing and ground-truth assessments) should be focused on other mangrove patches in the south of the present study zone (Yingluo Bay) and other mangrove areas in
ZMNNR (i.e. Beitan, Techeng, Taiping, Fucheng, Qishui, $\mathrm{He}$ ' an and Tuli) for a complete monitoring and more efficient management.

Acknowledgements. We wish to express our sincere gratitude to the authorities at F.R.S.-FNRS (Fonds de la Recherche Scientifique), Brussels, Belgium, for funding this project. B. Satyaranayana is supported by the Belgian National Science Foundation (\# F6/15 - MCF/OL Convention no. 2.4532.09). Special thanks are due to all people who have helped us during the fieldwork, especially the students from the Guangdong Ocean University.

Edited by: S. W. A. Naqvi

\section{References}

Bouyoucos, G. J.: Hydrometer Method Improved for Making Particle Size Analyses of Soils, Agron. J., 54, 464-465 1962.

Chapman, V. J.: Mangrove vegetation, Strauss and Cramer, Vaduz, 499 pp., 1976.

Chen, G. C. and Ye, Y.: Restoration of Aegiceras corniculatum mangroves in Jiulongjiang Estuary changed macrobenthic faunal community, Ecol. Eng., 37, 224-228, doi:10.1016/j.ecoleng.2010.10.003, 2011.

Chen, L. Z., Wang, W. Q., Zhang, Y. H., and Lin, G. H.: Recent progresses in mangrove conservation, restoration and research in China, J. Plant. Ecol.-UK, 2, 45-54, doi:10.1093/Jpe/Rtp009, 2009.

Cintron, G. and Schaeffer Novelli, Y.: Methods for studying mangrove structure, UNESCO, Paris, INTERNATIONAL, 1984.

Cottam, G. and Curtis, J. T.: The Use of Distance Measures in Phytosociological Sampling, Ecology, 37, 451-460, 1956.

Dahdouh-Guebas, F.: The use of remote sensing and GIS in the sustainable management of tropical coastal ecosystems, Environ. Develop. Sustain., 4, 93-112, doi:10.1023/a:1020887204285, 2002.

Dahdouh-Guebas, F. and Koedam, N.: Coastal vegetation and the Asian tsunami, Science, 311, 37-37, 2006a.

Dahdouh-Guebas, F. and Koedam, N.: Empirical estimate of the reliability of the use of the Point-Centred Quarter Method (PCQM): Solutions to ambiguous field situations and description of the PCQM plus protocol, Forest Ecol. Manag., 228, 1-18, doi:10.1016/j.foreco.2005.10.076, 2006b.

Dahdouh-Guebas, F. and Koedam, N.: Long-term retrospection on mangrove development using transdisciplinary approaches: A review, Aquat. Bot., 89, 80-92, doi:10.1016/j.aquabot.2008.03.012, 2008.

Dahdouh-Guebas, F., Zetterstrom, T., Ronnback, P., Troell, M., Wickramasinghe, A., and Koedam, N.: Recent changes in landuse in the Pambala-Chilaw Lagoon Complex (Sri Lanka) investigated using remote sensing and GIS : conservation of mangroves vs. development of shrimp farming, Environ. Develop. Sustain., 4, 185-200, 2002.

Dahdouh-Guebas, F., Van Hiel, E., Chan, J., Jayatissa, L., and Koedam, N.: Qualitative distinction of congeneric and introgressive mangrove species in mixed patchy forest assemblages using high spatial resolution remotely sensed imagery (IKONOS), Syst. Biodivers., 2, 113-119, 2004. 
Dahdouh-Guebas, F., Collin, S., Lo Seen, D., Ronnback, P., Depommier, D., Ravishankar, T., and Koedam, N.: Analysing ethnobotanical and fishery-related importance of mangroves of the East-Godavari Delta (Andhra Pradesh, India) for conservation and management purposes, J. Ethnobiol. Ethnomed., 2, 24, 138166, doi:10.1201/b14535-8, 2006a.

Dahdouh-Guebas, F., Verheyden, A., Kairo, J. G., Jayatissa, L. P., and Koedam, N.: Capacity building in tropical coastal resource monitoring in developing countries: A re-appreciation of the oldest remote sensing method, Int. J. Sust. Dev. World, 13, 62-76, 2006b.

Duke, N. C., Meynecke, J. O., Dittmann, S., Ellison, A. M., Anger, K., Berger, U., Cannicci, S., Diele, K., Ewel, K. C., Field, C. D., Koedam, N., Lee, S. Y., Marchand, C., Nordhaus, I., and Dahdouh-Guebas, F.: A world without mangroves?, Science, 317, 41-42, 2007.

Gao, X.-M., Han, W.-D., and Liu, S.-Q.: The mangrove and its conservation in Leizhou Peninsula, China, J. Forest. Res., 20, 174 178, doi:10.1007/s11676-009-0032-0, 2009.

Giri, C., Ochieng, E., Tieszen, L. L., Zhu, Z., Singh, A., Loveland, T., Masek, J., and Duke, N.: Status and distribution of mangrove forests of the world using earth observation satellite data, Global Ecol. Biogeogr., 20, 154-159, doi:10.1111/j.14668238.2010.00584.x, 2011.

Green, E. P., Mumby, P. J., Edwards, A. J., and Clark, C. D.: Remote Sensing Handbook for tropical Coastal management, Coastal Management Sourcebooks 3, 316 pp., 2000.

Hamilton, L., Dixon, J., and Miller, G.: Mangroves: an undervalued resource of the land and the sea, Ocean Yearbook, 8, 254-288, 1989.

He, B. Y., Lai, T. H., Fan, H. Q., Wang, W. Q., and Zheng, H. L.: Comparison of flooding-tolerance in four mangrove species in a diurnal tidal zone in the Beibu Gulf, Estuar. Coast Shelf S., 74, 254-262, doi:10.1016/j.ecss.2007.04.018, 2007.

Li, M. S. and Lee, S. Y.: Mangroves of China: a brief review, Forest Ecol. Manag., 96, 241-259, 1997.

Liang, S. C. and Dong, M.: Spatial heterogeneity of population structure of the mangrove Bruguiera gymnorrhiza at Yingluo Bay, South-China Coast, Acta Bot. Sin., 46, 1015-1024, 2004.

Masso i Aleman, S., Bourgeois, C., Appeltans, W., Vanhoorne, B., De Hauwere, N., Stoffelen, P., Heughebaert, A., and Dahdouh-Guebas, F.: The "Mangrove Reference Database and Herbarium", Plant Ecol. Evol., 143, 225-232, doi:10.5091/plecevo.2010.439, 2010.

Nagelkerken, I., Blaber, S. J. M., Bouillon, S., Green, P., Haywood, M., Kirton, L. G., Meynecke, J. O., Pawlik, J., Penrose, H. M., Sasekumar, A., and Somerfield, P. J.: The habitat function of mangroves for terrestrial and marine fauna: A review, Aquat. Bot., 89, 155-185, doi:10.1016/j.aquabot.2007.12.007, 2008.

Neukermans, G., Dahdouh-Guebas, F., Kairo, J. G., and Koedam, N.: Mangrove species and stand mapping in GAzi bay (Kenya) using Quickbird satellite imagery, J. Spat. Sci., 53, 75-86, 2008.
Primavera, J. H.: Tropical shrimp farming and its sustainability, in: Tropical mariculture, edited by: Diego, A. P. S., 257-289, 1998.

Ramsar Sites information Service: http://www.ramsar.wetlands.org/ Database/Searchforsites/tabid/765/Default.aspx (last access: 3 February 2010), 2009.

Ren, H., Jian, S. G., Lu, H. F., Zhang, Q. M., Shen, W. J., Han, W. D., Yin, Z. Y., and Guo, Q. F.: Restoration of mangrove plantations and colonisation by native species in Leizhou bay, South China, Ecol. Res., 23, 401-407, doi:10.1007/s11284-007-03939, 2008.

Ren, H., Wu, X. M., Ning, T. Z., Huang, G., Wang, J., Jian, S. G., and $\mathrm{Lu}, \mathrm{H}$. F.: Wetland changes and mangrove restoration planning in Shenzhen Bay, Southern China, Landsc. Ecol. Eng., 7, 241-250, doi:10.1007/s11355-010-0126-z, 2011.

Rönnbäck, P.: The ecological basis for economic value of seafood production supported by mangrove ecosystems, Ecol. Econom., 29, 235-252, doi:10.1016/s0921-8009(99)00016-6, 1999.

Satyanarayana, B., Idris, I. F., Mohamad, K. A., Husain, M. L., Shazili, N. A. M., and Dahdouh-Guebas, F.: Mangrove species distribution and abundance in relation to local environmental settings: a case-study at Tumpat, Kelantan Delta, east coast of peninsular Malaysia, Bot. Mar., 53, 79-88, doi:10.1515/Bot.2010.006, 2010.

Satyanarayana, B., Koedam, N., De Smet, K., Di Nitto, D., Bauwens, M., Jayatissa, L. P., Cannicci, S., and DahdouhGuebas, F.: Long-term mangrove forest development in Sri Lanka: early predictions evaluated against outcomes using VHR remote sensing and VHR ground-truth data, Mar. Ecol. Progr. S., 443, 51-63, doi:10.3354/meps09397, 2011.

Spalding, M., Kainuma, M., and Collins, L.: World Atlas of Mangroves, Earthscan Publications Ltd., UK, 319 pp., 2010.

Tam, N. F. Y., Wong, Y. S., Lu, C. Y., and Berry, R.: Mapping and characterization of mangrove plant communities in Hong Kong, Hydrobiologia, 352, 25-37, 1997.

Valiela, I., Bowen, J., and York, J.: Mangrove Forests: One of the World's Threatened Major Tropical Environments, Bioscience, 51, 807-815, 2001.

Walters, B. B., Rönnbäck, P., Kovacs, J. M., Crona, B., Hussain, S. A., Badola, R., Primavera, J. H., Barbier, E., and Dahdouh-Guebas, F.: Ethnobiology, socio-economics and management of mangrove forests: A review, Aquat. Bot., 89, 220 236, doi:10.1016/j.aquabot.2008.02.009, 2008.

Ye, Y., Tam, N. F. Y., Wong, Y. S., and Lu, C. Y.: Growth and physiological responses of two mangrove species (Bruguiera gymnorrhiza and Kandelia candel) to waterlogging, Environ. Exp. Bot., 49, 209-221, 2003.

Ye, Y., Tam, N. F. Y., Lu, C. Y., and Wong, Y. S.: Effects of salinity on germination, seedling growth and physiology of three salt-secreting mangrove species, Aquat. Bot., 83, 193-205, doi:10.1016/j.aquabot.2005.06.006, 2005.

Zhanjiang Mangrove National Nature Reserve: http://www. zjmangrove.org/en/about.asp (last access: August 2010), 2010. 